VOX PATRUM 37 (2017) t. 68

Eirini ARTEMI*

\title{
THE DIVINE PERSONHOOD OF THE HOLY SPIRIT IN THE TEACHING OF GREGORY NAZIANZEN
}

1. The question of the deity of the Holy Spirit after the post-Nicene debate for Logos. A major heresy that arose in the fourth century and denied the divinity of Jesus Christ was Arianism. Arius (256-336), a priest of Alexandria, denied that there were three distinct divine Persons in God. For Arius, there was only one Person, the Father. According to Arian's theory, the Son was created:

"If the Father begot the Son, he that was begotten had a beginning of existence: and from this it is evident, that there was a time when the Son was not. It therefore necessarily follows, that he had his substance from nothing"1.

Christ was thus a son of God, not by nature, but only by grace and adoption ${ }^{2}$. This theory logically emptied the doctrine of the Incarnation of God in Christ of all meaning: if God did not become man, then the world has not been redeemed and the faith itself eventually dissolves. Arianism was formally condemned in 325 by the first ecumenical Council of Nicaea, which formulated and promulgated the original version of the Nicene Creed; but Arianism and Semi-Arianism nevertheless continued to prevail in its original form in many areas for more than a century. Arianism was combated by the great St. Athanasius of Alexandria (296-373) among others; but the heresy nevertheless persisted, especially among the barbarians, for several centuries ${ }^{3}$.

${ }^{*}$ Dr Eirini Artemi - Theologist \& Classical Philologist, Post Doc of Ancient Greek and Byzantine Philosophy of University of Patras, MA \& Ph.D. of Theology of National and Capodistrian University of Athens, Lecturer in the Hellenic Open University, email: eartemi@theol.uoa.gr.

${ }^{1}$ Cf. Socrates, HE I 5, 6, PG 67, 41B, transl. A.C. Zenos, NPNF Series II, vol. 2, ed. P. Schaff - H. Wace, Buffalo - New York 1890, 3.

${ }^{2}$ Cf. Athanasius Alexandrinus, Orationes adversus Arianos I 5, 6, PG 26, 41B.

${ }^{3}$ Among the barbarians, Arianism took on a life of its own. Christianity in its Arian form became somewhat unique, distinct even from native Roman Arianism. The new kingdoms also became religiously-layered, with the Germanic aristocracy being Arian with the majority Roman population being Catholic (with a minority of Arians among the Romans). This chagrined the Catholic hierarchy, and they feared repression. But generally the barbarian kings tolerated the Catholics in their lands; they did, however, intervene when the Catholics targeted Arianism. The kings often sheltered outspoken Arians, giving this heresy something of a haven and allowing it to persist even in places they did not control. Cf. Ch.J. Nofziger, Reign of heretics: Arianism and political power in 
Some years later after the First Ecumenical Council, the heresy of Pneumatomachians, "fighters against the Spirit" appeared who denied the consubstantiality of the Holy Spirit with the Father in the divine Trinity. Generally, although Arius' argument for the uniqueness of the Father's ousia implied that the Spirit, like the Son, was not the Father's ontological equal, the real dispute was between pro-Nicenes and a faction of Homoeousians called Pneumatomachians who were followers of Macedonius of Constantinople ${ }^{4}$.

$\mathrm{He}$ and his followers denied the divinity of the Holy Spirit: the Spirit was declared by them not to proceed from the Father but to be a creation of the Son. The Holy Spirit is a divine energy diffused throughout the universe, and not a person distinct from the Father and the Son. So he underlined with emphasis that the Holy Spirit is not consubstantial with the Father and the Son in divinity. If the Holy Spirit proceeded from the Father and was sent by the Father and the Son, and was a messenger, He is not equal with Them. Therefore, He is subordinate to Them ${ }^{5}$.

Since this heresy had spread throughout the Eastern Churches, $150 \mathrm{Bi}-$ shops were assembled in Constantinople in 381. At this great Council, the Holy Fathers quoting from the Old and New Testaments officially proclaimed, that even though the Holy Spirit proceeded from the Father, He is equal with the Father and the Son in nature, divinity and glory 6 . After explaining this at great length, they ascertained the divinity of the Holy Spirit and they vehemently condemned Macedonius and his heretical teaching ${ }^{7}$. The defence of the deity of the Spirit was based mostly on the theology of Gregory Nazianzen.

\section{Gregory Nazianzen drew attention to the opinions that existed for} the Holy Spirit. A formal doctrine of the Holy Spirit was not articulated until the early third century. On this point, there was scriptural silence. In his forty first oration On Pentecost $t^{8}$, Gregory Nazianzen dealt with the same subject of his Fifth Theological Oration, the question of the Deity of the Holy Ghost, but proceeded to establish the point by quite a different set of arguments from those adopted in the former discourse ${ }^{9}$.

He drew attention to some groups of "Christians" who rejected the personhood as well as the divinity of the Holy Spirit are. To them the Holy Spirit was

the Vandal and Ostrogothic kingdoms, Western Washington University, Masters Thesis Collection, Washington 2012.

${ }^{4}$ Cf. Socrates, HE II 45, 1-23, PG 67, 357B-360B.

${ }^{5} \mathrm{Cf}$. ibidem.

${ }^{6}$ Cf. J. Romanides, Dogmatic and Symbolic Theology of the Orthodox Catholic Church, vol. 1, Athens 1960, 242. Cf. Ps 33:6, Is 6:3, Acts 28:25.

${ }^{7}$ Cf. S. Papadopoulos, Patrologia, vol. 2, Athens 1990, 536-537; V. Feidas, Ecclesiastic History, vol. 1, Athens 1992, 520-521.

${ }^{8}$ Cf. Gregorius Nazianzenus, Oratio 41 (In Pentecosten), PG 36, 428-452.

${ }^{9} \mathrm{Cf}$. ibidem. 
not God ${ }^{10}$. The Holy Spirit is spoken of as a "force", or as "power" emanating from God, rather than as God himself ${ }^{11}$. He was thought of as a creature ${ }^{12}$. He was denied not only by the Arians but also by those referred to as "Spiritfighters (Pneumatomachoi)", who accepted the deity of the Son but denied the deity of the Spirit. The Arians and the Pneumatomachoi influenced by Origen, were the major opponents Gregory had to face in proclaiming that the Holy Spirit was none other than God himself ${ }^{13}$. Origen, an Alexandrian theologian had a conflicted view of the Holy Spirit. On the one hand he taught that the Spirit "was made by the Word, and that the Word is the elder of the two"14, and on the other hand he supported that the Holy Spirit is part of the Trinity ${ }^{15}$. He also recognized that the apostolic teaching did not detail how the Holy Spirit is a full member of the Trinity ${ }^{16}$, as an individual substantial entity and not an abstraction. The Spirit is not the energy, or wisdom, of God, but an active and real substance, represented in the Holy Bible as acting personally ${ }^{17}$. Origen stated that:

"The God and Father, who holds the universe together, is superior to every being that exists, for he imparts to each one from his own existence that which each one is; the Son, being less than the Father, is superior to rational creatures alone (for he is second to the Father); the Holy Spirit is still less, and dwells within the saints alone. So that in this way the power of the Father is greater than that of the Son and of the Holy Spirit, and that of the Son is more

\footnotetext{
${ }^{10}$ Cf. idem, Oratio 31 (Theologica Quinta - De Spiritu Sancto), 5, PG 36, 137C.

${ }^{11} \mathrm{Cf}$. ibidem.

${ }^{12}$ Cf. idem, Oratio 41 (In Pentecosten), 6, PG 36, 437A, transl. C.G. Browne - J.E. Swallow,
} NPNF Series II, vol. 7, ed. P. Schaff - H. Wace, Buffalo - New York 1894, 381: “They who reduce the Holy Spirit to the rank of a creature are blasphemers and wicked servants, and worst of the wicked. For it is the part of wicked servants to despise Lordship, and to rebel against dominion, and to make That which is free their fellow-servant".

${ }^{13}$ Cf. idem, Oratio 31 (Theologica Quinta - De Spiritu Sancto), 5, PG 36, 137C.

${ }^{14}$ Cf. C.F. Lo, Gregory Nazianzen's Pneumatology completes the $4^{\text {th }}$ century trinitarian theology, The Johns Hopkins University, Charlotte, North Carolina 2011, 4; H.B. Swete, The Holy Spirit in the Ancient Church, London 1912, 127.

${ }^{15}$ Cf. Origenes, De principiis I 3, 7-8, ed. P. Koetschau, transl. G.W. Butterworth: Origen, On First Principles, New York 1973, 34.

${ }^{16}$ Cf. ibidem, Praefatio I 4, transl. Butterworth, p. 4: "Then again, the apostles delivered this doctrine, that the Holy Spirit is united in honor and dignity with the Father and the Son. In regard to him it is not yet clearly known whether he is to be thought of as begotten or unbegotten, or as being himself also a Son of God or not; but these are matters which we must investigate to the best of our power from holy scripture, inquiring with wisdom and diligence. It is, however, certainly taught with the utmost clearness in the Church, that the Spirit inspired each of the saints, both the prophets and the apostles, and that there was not one Spirit in the men of old and another in those who were inspired at the coming of Christ".

${ }^{17}$ Cf. ibidem I 3, 1-5, transl. Butterworth, p. 33. 
than that of the Holy Spirit, and in turn the power of the Holy Spirit exceeds that of every other holy being"18.

On the other hand he attributed the work of creation and sanctification to the Spirit, as well as placing the Spirit in the realm of the divine rather than in the realm of the creation. Therefore, the Holy Spirit is worthy of equal honor to the Son and the Father ${ }^{19}$. Taken to its logical conclusion, the Spirit cannot be co-equal with the Father since He also had a beginning. So from this part of his writing, Arians would teach that it was the Son who created the Holy Spirit, borrowing from Origen's concept of subordinationism ${ }^{20}$.

Others thought that the Spirit belonged to a "third-thing" that is neither God nor a creature, but a composite or a mixture ${ }^{21}$. Of course, some Christians supported that the third Person of the Triune God was God, but few of them expressed it in public. Gregory belonged to the group who were willing to champion the position that the Holy Spirit is God ${ }^{22}$. For him, the Holy Spirit is fully God, just as the Son is fully God ${ }^{23}$. This hesitancy and ambiguity in the early church about the deity of the Spirit made it easy for the Pneumatomachians to continue their quest to depreciate the Holy Spirit. To Gregory, the deity of the Holy Spirit needed to be openly and forcefully confessed, since the doctrine and the life of the Church depended on $\mathrm{it}^{24}$.

But, there was another group of "Christians" who neither honored the Holy Spirit as God, because something like that wasn't referred in Scripture, nor thought of Him as a creature. They preferred to stay silent in regards to the deity of Spirit ${ }^{25}$. So they repeated words of Eustathius Bishop of Sebastia: "I can neither admit that the Holy Spirit is God, nor can I dare affirm him to be a creature" 26 .

Generally, it could be said that there were many and different opinions about the Holy Spirit, mainly in the third and fourth century because as some trinita-

${ }^{18} \mathrm{Cf}$. ibidem I 3, 5, transl. Butterworth, p. 33-34. This passage is omitted in the Latin translation of Rufinus.

${ }^{19}$ Cf. Lo, Gregory Nazianzen's Pneumatology, p. 4; Swete, The Holy Spirit in the Ancient Church, p. 127.

${ }^{20}$ Cf. Swete, The Holy Spirit in the Ancient Church, p. 165; B. Cash, Origen's Trinitarian Theology, New York 2010, 10: "Subordinationism is the belief that the Father was the Supreme Being, from which all other things derived their existence, including the Son and the Spirit. It proposed that the Son and Spirit were subordinate to the Father in nature and being".

${ }^{21}$ Cf. Gregorius Nazianzenus, Oratio 31 (Theologica Quinta - De Spiritu Sancto), 5, PG 36, 137C-D; idem, Oratio 13 (Habita in consecratione Eulalii Doarensium episcopi) 4, PG 35, 856B.

${ }^{22}$ Cf. Socrates, HE II 45, 1-23, PG 67, 357B - 360B.

${ }^{23}$ Cf. Gregorius Nazianzenus, Epistula 58, PG 37, 113-117, NPNF Series, vol. 7, 453.

${ }^{24} \mathrm{Cf}$. S. Papadopoulos, Gregory the theologian and the presuppositions of his pneumatology, vol. 2, Athens 1989³, 73-74; Lo, Gregory Nazianzen's Pneumatology, p. 18.

${ }^{25}$ Cf. Lo, Gregory Nazianzen's Pneumatology, p. 18.

${ }^{26}$ Cf. Socrates, HE II 45, 12, PG 67, 357B-C. 
rian scholars argued, the biblical koine Greek language of the New Testament allowed the Holy Spirit to be understood as an impersonal force or influence more readily than it does the $\mathrm{Son}^{27}$. Of course it should not be ignored that the usage of the word "paraclete" ( $\pi \alpha \rho \alpha ́ \kappa \lambda \eta \tau ం \varsigma)$ for the Holy Spirit (cf. Jn 14:16. $26 ; 15: 26 ; 16: 7)$ which can be translated as advocate, intercessor, counsellor or protector, and the Holy Spirit's essence and action was characterized by truth, as all three persons of the Trinity are linked with truth, are seen as arguments that the Holy Spirit is a divine person; especially that Jesus calls Him another counselor, in this way expressing that the Holy Spirit is similar to Himself in regard to our counselor. This form of the word is unquestionably passive and properly means "one called to the side of another"; the word carries a secondary notion concerning the purpose of the calling alongside: to counsel or support the one who needs it. This Counselor, or Paraclete, is God the Holy Spirit, the third Person of the Trinity who has been "called to our side". He is a personal being, and He indwells every believer.

Also there were some other reasons that delayed the development of the dogmatic teaching of the Holy Spirit. In particular, a teaching about the deity of the Holy Spirit was not widely accepted until the fourth century, for the following reasons: 1 . the deeds of the Holy Spirit could be attributed to an impersonal force from $\mathrm{God}^{28}, 2$. second-century heretics were associated with treating the Holy Spirit as a person, 3. early Church writers, such as Irenaeus of Lyon ${ }^{29}$ and the apologist Athenagoras ${ }^{30}$, made statements contradicting the current trinitarian view of the Holy Spirit. Generally, in fact they were making an arduous effort to draw a real and absolute distinction between "Logos" and

${ }^{27}$ Cf. H.O.J. Brown, Heresies: Heresy and Orthodoxy in the History of the Church, Peabody $1988,140$.

${ }^{28}$ Cf. Gregorius Nyssenus, Epistula 189, 4, PG 32, 688D - 689A, transl. H.A. Wilson, NPNF Series II, vol. 5, ed. P. Schaff - H. Wace, Buffalo - New York 1893, 327: "But they reveal more clearly the aim of their argument. As regards the Father, they admit the fact that $\mathrm{He}$ is God, and that the Son likewise is honoured with the attribute of Godhead; but the Spirit, Who is reckoned with the Father and the Son, they cannot include in their conception of Godhead, but hold that the power of the Godhead, issuing from the Father to the Son, and there halting, separates the nature of the Spirit from the Divine glory".

${ }^{29}$ Cf. Irenaeus, Adversus haereses IV, Praefatio 4, PG 7, 975C, transl. A. Roberts - W. Rambaut, ANF I, ed. A. Roberts - J. Donaldson - A.C. Coxe, Buffalo - New York 1885, 463: "there is none other called God by the Scriptures except the Father of all, and the Son, and those who possess the adoption".

${ }^{30}$ Cf. Athenagoras, Legatio pro Christianis 10, PG 6, 908B - 909B, transl. B.P. Pratten, ANF 2, ed. A. Roberts - J. Donaldson - A.C. Coxe, Buffalo - New York 1885, 133: “And, the Son being in the Father and the Father in the Son, in oneness and power of spirit, the understanding and reason

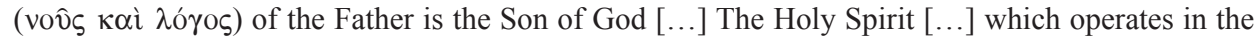
prophets, we assert to be an effluence ( $\alpha \pi$ óppor $\alpha$ ) of God, flowing from Him, and returning back again like a beam of the sun [...] Who, then, would not be astonished to hear men who speak of God the Father, and of God the Son, and of the Holy Spirit and who declare both their power in union and their distinction in order, called atheists? [...] the Spirit an effluence, as light from fire". 
"Spirit", because of the very extensive use which was made of the concept of "Logos" 31.

Harold O.J. Brown explained that: "The attempt to develop an understanding of the Holy Spirit consistent with the trinitarian passages came to fruition at Constantinople in 381. There were a number of reasons why the personhood of the Holy Spirit took longer to acknowledge than the Son: i) the term pneuma, breath, is neuter in general and impersonal in ordinary meaning ${ }^{32}$; ii) the distinctive work of the Holy Spirit, influencing the believer, does not necessarily seem as personal as that of the Father and in addition, those who saw the Holy Spirit as a Person, were often heretical, for example, the Montanists ${ }^{33}$; iii) many of the early theologians attributed to the Logos or Word, the revelatory activity later theologians saw as the special, personal work of the Holy Spirit" ${ }^{34}$.

3. The pneumatology of Gregory Nazianzen. Gregory is a saint in both Eastern and Western Christianity. In the Roman Catholic Church he is numbered among the Doctors of the Church ${ }^{35}$; in Eastern Orthodoxy and the Eastern Catholic Churches he is revered as one of the Three Holy Hierarchs,

${ }^{31}$ Cf. G.H. Lampe, Christian Theology in Patristic Period, in: A History of Christian Doctrine, ed. H. Cunliffe-Jones - B. Drewery, Edinburgh 1978, 21-180, 37.

${ }^{32}$ Of course, the word "Spirit" in Greek is a neuter term. But this does not necessarily mean the Holy Spirit is impersonal. In Greek language the grammatical gender is often different from the natural gender.

${ }^{33}$ Cf. Ch. Trevett, Montanism: Gender, Authority and the New Prophecy, Cambridge 1996; S. Papadopoulos, Patrologia, vol. 1, Athens 1992, 256- 259. The professor B. Stefanides writes that Montanism was not a heresy but a schismatic movement, because its teaching had nothing to do with the dogmatic teaching of the Church. Montanus wanted to maintain the enthusiastic actions of Christians that began to be disappeared. Cf. B. Stefanides, Church History, Athens 1959, 79-80.

${ }^{34}$ Cf. Brown, Heresies: Heresy and Orthodoxy, p. 140.

${ }_{35}$ Cf. S. Reynolds, Introduction, in: Gregory of Nazianzus, Five Theological Orations, Translated with an introduction and notes by S. Reynolds, Toronto 2011, V [= https://tspace.library. utoronto.ca/bitstream/1807/36303/1/Gregory\%20of\%20Nazianzus\%20Theological\%20Orations. pdf (access 15.03.2017)]: "The western Catholic tradition has ranked him among «the Four Doctors of the Eastern Church» and honoured him on May $9^{\text {th }}$. The other three are Basil the Great, John Chrysostom, and Cyril of Alexandria. «The Four Doctors of the Western Church» are Ambrose of Milan, Augustine of Hippo, Jerome, and Gregory the Great. Doctor, of course, is the Latin word for «teacher» - as in the BAS designation, «Teacher of the Faith». When the Roman Catholic church revised its Calendar in 1969, Gregory was joined with Basil the Great in a single memorial on January $2^{\text {nd }}$. In the Calendar of the Anglican Church of Canada's Book of Common Prayer (1962), Gregory is to be commemorated on the traditional western date, May $9^{\text {th }}$. The Calendar of the church's Book of Alternative Services (1985) adopted the new Roman usage and appoints Gregory's memorial, with Basil the Great, on January $2^{\text {nd }}$. Basil died on January 1 st in 379 ; the Orthodox continue to honour him, alone, on that date. In the Roman Calendar of 1969, however, January 1st is now the Solemnity of Mary the Mother of God; the BAS Calendar made the same date the festival of the Baptism of the Lord. Since feasts of our Lord (and, in the mentalité of Roman Catholicism, any feast of our Lady is tantamount to a feast of our Lord) take precedence over all other festivals, the memorial of Basil and Gregory had to be postponed by one day". 
along with Basil the Great and John Chrysostom ${ }^{36}$. He is also one of only three men in the life of the Orthodox Church who have been officially designated "Theologian" by epithet, the other two being St. John the Theologian (the Evangelist), and St. Symeon the New Theologian ${ }^{37}$. Gregory's most significant theological contributions arose from his defense of the doctrine of the Trinity. He is especially noted for his contributions to the field of pneumatology - that is, theology concerning the nature of the Holy Spirit ${ }^{38}$.

Gregory was one of the first theologians who supported the position that the Holy Spirit is a distinct person of the Triune God, so He is God. In 372, he emphasized that we should worship God the Father, God the Son and God the Holy Spirit, three hypostases, but in one essence, glory and light ${ }^{39}$.

Gregory realized that the term "God" was not reserved for the Holy Spirit in the Scriptures in a clear manner, but this was not cause for the refusal of the deity of the Holy Spirit because he insisted that Holy Spirit was God:

"Over and over again you turn upon us the silence of Scripture. But that it is not a strange doctrine, nor an afterthought, but acknowledged and plainly set forth both by the ancients and many of our own day, is already demonstrated by many persons who have treated of this subject, and who have handled the Holy Scriptures, not with indifference or as a mere pastime, but have gone beneath the letter and looked into the inner meaning, and have been deemed worthy to see the hidden beauty, and have been irradiated by the light of knowledge. We, however in our turn will briefly prove it as far as may be, in order not to seem to be over-curious or improperly ambitious, building on another's foundation. But since the fact, that Scripture does not very clearly or very often write Him God in express words (as it does first the Father and afterwards the Son), becomes to you an occasion of blasphemy and of this excessive wordiness and impiety, we will release you from this inconvenience by a short discussion of things and names, and especially of their use in Holy Scripture"

We should not forget that in Nicene dogmatic theology there are the words "Trinity" and "homoousios" which are not in the Holy Bible as the terms themselves, but we can find them periphrastically in Scriptures. By this way Gregory answered to the argument of the believers in the refusal of the Holy

${ }^{36}$ Cf. J.A. McGuckin, St. Gregory of Nazianzus: An Intellectual Biography, Crestwood - New York 2001, 17.

${ }^{37}$ Cf. E. Artemi, Gregory Nazianzen's trinitarian teaching based on his Twentieth Theological Oration, "De Medio Aevo" 4 (2013) fasc. 2, 127.

${ }^{38}$ Cf. McGuckin, St. Gregory of Nazianzus, p. 20.

${ }^{39}$ Cf. Gregorius Nazianzenus, Oratio 13 (Habita in consecratione Eulalii Doarensium episcopi), 4, PG 35, 856B.

${ }^{40}$ Idem, Oratio 31 (Theologica Quinta - De Spiritu Sancto), 21, PG 36, 156C - 157A, NPNF Series II, vol. 7, 324. 
Spirit's deity: "Where did you get this strange, unscriptural «God» you are bringing in?" 41.

He explained that the Holy Spirit is equal with the Son and the Father, and they are called with one name as God. On the other hand the essence of these three persons, who are not separable from one another as to be neither divided in nature, nor so contracted as to be circumscribed by a single person, is creative, and originating, and unchangeable. Only was the essence of the creatures created, and subject and changing ${ }^{42}$. This is the great difference between the Creator and creation. And of course the God Spirit as real God has all the common characteristics of the other two persons of the Holy Trinity, the Father's causality and the word's Sonship ${ }^{43}$. But Gregory underlined that the Holy Spirit is not God's creature nor unequal to the Father, because this was something that Arians ${ }^{44}$ said about the Son and, by extension, to the Spirit. Additionally the Cappadocian father explained that it should not be regarded the Spirit as another way for the presentation of God Father as Sabellian ${ }^{45} \operatorname{taught}^{46}$.

In his Homily for the celebration of the Feast of Pentecost, he found the chance to speak again for the deity of the Holy Spirit. He invoked the assistance of the Spirit for his preaching, he immediately picked up on the distinction between dominion and servitude that he introduced in Oration 34 On the Arrival of the Egyptians. By this way, he unquestionably highlighted the deity of the Holy Spirit:

"As to the things of the Spirit, may the Spirit be with me, and grant me speech as much as I desire; or if not that, yet as is in due proportion to the season. Anyhow He will be with me as my Lord; not in servile guise, nor awaiting a command, as some think.For He bloweth where $\mathrm{He}$ wills and on whom $\mathrm{He}$ wills, and to what extent He wills. Thus we are inspired both to think and to speak of the Spirit" ${ }^{47}$.

\footnotetext{
${ }^{41}$ Ibidem 31, 1, PG 36, 133B, NPNF Series II, vol. 7, 318, my own translation.

${ }^{42}$ Cf. idem, Oratio 34 (In Aegyptiorum Adventum), 8, PG 36, 249A.

${ }^{43} \mathrm{Cf}$. ibidem 10, PG 36, 252A.

${ }^{44} \mathrm{P}$. Schaff (History of the Christian Church. Third Period the church in union with the Roman Empire from Constantine the Great to Gregory the Great, A.D. 311-590, vol. 3, New York 1997, 663-664) holds that: "The Arians made the Holy [Spirit] the first creature of the Son, and as subordinate to the Son as the Son to the Father. The Arian trinity was therefore not a trinity immanent and eternal, but arising in time and in descending grades, consisting of the uncreated God and two created demi-gods. The Semi-Arians here, as elsewhere, approached the orthodox doctrine, but rejected the consubstantiality, and asserted the creation of the Spirit".

${ }^{45}$ Sabellius evidently taught that the Godhead is a monad, expressing itself in three operations: as Father, in creation; as Son, in redemption; and as Holy Spirit, in sanctification. Cf. Papadopoulos, Patrologia, vol. 1, p. 383-384; P. Christou, Patrologia, vol. 1, Thessaloniki 2005, 842-844.

${ }^{46}$ Cf. Gregorius Nazianzenus, Oratio 34 (In Aegyptiorum Adventum), 8, PG 36, 249A.

${ }^{47}$ Idem, Oratio 41 (In Pentecosten), 5, PG 36, 436C - 437A, NPNF Series II, vol. 7, 381.
} 
Also Gregory explained that the Holy Spirit is real God and if someone tried to cheat Him, he would blaspheme against the divine essence of the Spirit. This blasphemy was made manifest to Ananias by the apostle Peter in Acts $^{48}$. In this passage of the Acts, Ananias and his wife Sapphira lied about their proceeds from the sale of their land. So Peter rebuked him for his lies and stated that Ananias had lied not to men, but to $\mathrm{God}^{49}$. If the Holy Spirit was not God, homoousios with the God Father, He could not be named as God in the above passage of Acts.

For Gregory, the Holy Spirit was beyond human comprehension. He always was and is and will be, without beginning, without end, but is always ranked and numbered with the Father and the Son. He is in a mutual relationship with the Father and the Son ${ }^{50}$. For it was not at any time fitting that the Son be lacking to the Father, or the Spirit to the Son ${ }^{51}$. According Gregory's pneumatology, the Spirit, as God, is always the same as himself and as those with whom he is ranked, invisible, eternal, uncontainable, unchanging, without quality, without quantity, without form, intangible, self-moving, evermoving, self-determining, self-powered and all-powerful ${ }^{52}$. Also, he clearly put forward his position regarding the deity of the Holy Spirit by stating that all attributes belonging to God the Father - and for that matter the Son - could equally apply to the Holy Spirit ${ }^{53}$. At the same time if one person of the Triune God existed from the beginning, so did all three ${ }^{54}$.

Finally, Gregory underlined with great emphasis and without a doubt that Spirit was God as Father and Son. We can realize God only in His revelation to us. It is only in God and through God that we can know God. It is only in

${ }^{48} \mathrm{Cf}$. Acts 5:1-10 [according to the King James Bible]: "But a certain man named Ananias, with Sapphira his wife, sold a possession and kept back part of the price, his wife also being privy to it, and brought a certain part of it and laid it at the apostles' feet. But Peter said, "Ananias, why hath Satan filled thine heart to lie to the Holy Ghost and to keep back part of the price of the land? While it remained, was it not thine own? And after it was sold, was it not in thine own power? Why hast thou conceived this thing in thine heart? Thou hast not lied unto men, but unto God». And Ananias, hearing these words, fell down and gave up the ghost. And great fear came on all those who heard these things. And the young men arose and wrapped him up, and carried him out and buried him. And it was about the space of three hours later when his wife, not knowing what was done, came in. And Peter said unto her, «Tell me whether ye sold the land for so much?» And she said, «Yea, for so much». Then Peter said unto her, «How is it that ye have agreed together to tempt the Spirit of the Lord? Behold, the feet of those who have buried thy husband are at the door and shall carry thee out». Then she fell down straightway at his feet and yielded up the ghost. And the young men came in and found her dead and, carrying her forth, buried her by her husband".

${ }^{49}$ Cf. Gregorius Nazianzenus, Oratio 31 (Theologica Quinta - De Spiritu Sancto), 30, PG 36, 168B-C; idem, Oratio 34 (In Aegyptiorum Adventum), 14, PG 36, 253C-D.

${ }^{50} \mathrm{Cf}$. idem, Oratio 41 (In Pentecosten), 9, PG 36, 144A.

${ }^{51}$ Cf. idem, Oratio 31 (Theologica Quinta - De Spiritu Sancto), 9, PG 36, 141C.

${ }^{52}$ Cf. idem, Oratio 41 (In Pentecosten), 9, PG 36, 441B-C.

${ }^{53}$ Cf. idem, Oratio 31 (Theologica Quinta - De Spiritu Sancto), 3, PG 36, $136 \mathrm{~B}$.

${ }^{54} \mathrm{Cf}$. ibidem 31, 4, PG 36, 137A. 
the divine light that we can see the divine light. Our knowledge of God enjoys a trinitarian structure: the Father is revealed through the incarnate Son in and by the illumination and transformative presence of the Holy Spirit ${ }^{55}$.

\section{The use of Bible by Gregory Nazianzen as proof for the deity if the} Holy Spirit. Although the word God is not referred to the Holy Spirit in the Bible, there are many passages that declare both directly and indirectly that the Holy Spirit is real God, homoousios with the other two persons of the Triune God, Father and Son. The indirect references for the divinity of the Holy Spirit are quite clear in the Scripture, so they can be thought of as direct testimony for the deity of Spirit.

It is without doubt that the Holy Spirit had a significant role in the creation of the world, in the salvation of man and in the universe generally. He had certain modes of presence in rational creatures. God revealed and reveals to us in His Word that the Holy Spirit's work has a far wider scope than this. We are taught in the Bible that the Holy Spirit has threefold work in the material universe. The creation of the latter and of man is effected through the agency of the Holy Spirit. First the Spirit acted in the angels, says Gregory:

"For from no other source flows their perfection and their brightness, and the difficulty or impossibility of moving them to sin, but from the Holy Ghost"56.

Then the Spirit acted in the patriarchs and prophets. To them he gave knowledge of God. To some he also gave foreknowledge of the future, allowing them to experience "future events as if they were present" the disciples of Christ, in three progressive stages: first, before Christ was glorified by the passion, the Holy Spirit distributed specific gifts of supernatural ministry, e.g., healing of the sick and exorcism of demons. In this mode the Spirit was manifested only indistinctly. Second, after Christ's resurrection from the dead, $\mathrm{He}$ appeared to his disciples and breathed upon them (cf. Jn 20:1-31.) Gregory does not tell us how he interprets the significance of this inbreathing, but it is plainly a "more divine inspiration" 58 . Finally, the Spirit came down upon the disciples in fiery tongues on the day of Pentecost $t^{59}$. The Pentecostal outpouring represents the Spirit coming to dwell in his Church, in his very being and personhood ${ }^{60}$.

Generally, Gregory used many verses from the Bible to prove that the deity of the Holy Spirit was not based on "the silence of Scripture" ${ }^{\text {. The }}$

${ }^{55}$ Cf. J. Zurab, Theologia and oikonomia: the soteriological ground of Gregory of Nazianzus trinitarian theology, Durham 2010, 58-109.

${ }^{56}$ Gregorius Nazianzenus, Oratio 41 (In Pentecosten), 11, PG 36, 444A, NPNF Series II, vol. 7, 383.

${ }^{57}$ Ibidem, PG 36, 444A-B, NPNF Series II, vol. 7, 383.

${ }^{58}$ Cf. Gregorius Nazianzenus, Oratio 41 (In Pentecosten), 11, PG 36, 444C.

${ }^{59} \mathrm{Cf}$. ibidem.

${ }^{60} \mathrm{Cf}$. ibidem.

${ }^{61}$ Idem, Oratio 31 (Theologica Quinta - De Spiritu Sancto), 21, PG 36, 156C, NPNF Series II, vol. 7, 324. 
Pneumatomachoi insisted on the letter of the Scripture. So they stayed in the written text and left the essence of the real meaning of the text of the Bible ${ }^{62}$, "their love for the letter is but a cloak for their impiety"63. But the real interpretation of Bible gave us the ability to handle the Holy Scriptures, not with indifference or as a mere pastime, but to go beneath the letter and look into the inner meaning, and have to be deemed worthy to see the hidden beauty, and to have been irradiated by the light of knowledge ${ }^{64}$.

Gregory argued that the Spirit is God, although this is not testimony based on specific words of the Scriptures, but on the meaning of the text of the Bible. In order to prove his thought, he explained that many hypostatical attributes of Father and Son don't exist as words in the Scripture's text, but they used for the dogmatic theology as regard Father and Son by the Fathers of the First Ecumenical Council (325):

"Again, where do you get your Unbegotten and Unoriginate, those two citadels of your position, or we our Immortal? Show me these in so many words, or we shall either set them aside, or erase them as not contained in Scripture; and you are slain by your own principle, the names you rely on being overthrown, and therewith the wall of refuge in which you trusted. Is it not evident that they are due to passages which imply them, though the words do not actually occur?" 65

Finally, in Gregory's mind everyone was guilty of blasphemy in the rejection of the Spirit's divinity, and hence, spiritually incapable of reading Scripture rightly. Christopher Beeley explained:

"Gregory realizes that the Bible does not call the Spirit «God» in plain terms, and he certainly believes that the doctrine of the Spirit must be based on Scripture. But in his mind the question is not whether or not one's doctrine is biblical, but how it is so, and what exactly this involves hermeneutically, theologically, and ecclesiastically" ${ }^{\prime 6}$.

$$
* * *
$$

The Holy Spirit is God. As God, He is homoousios with the Father and the Son. He is beyond place and time. He is the Spirit of adoption, of truth, of wisdom, of understanding, of knowledge, of piety, of counsel, of strength, of fear, through whom the Father is known and the Son glorified, and by whom alone $\mathrm{He}$ is known.

\footnotetext{
${ }^{62}$ Cf. ibidem 31, 24, PG 36, 160B.

${ }^{63}$ Ibidem 31, 3, PG 36, 136A, NPNF Series II, vol. 7, 318.

${ }^{64} \mathrm{Cf}$. ibidem 31, 21, PG 36, 156C.

${ }^{65}$ Cf. ibidem 31, 23, PG 36, $157 \mathrm{C}$.

${ }^{66} \mathrm{Ch}$. Beeley, Gregory of Nazianzus on the Trinity and the Knowledge of God, Oxford 2008, 165.
} 
Gregory accused the Pneumatomachoi of being slaves to the letter of the Scriptures as far as the deity of the Holy Spirit was concerned, and he explained that the terms of Nicene dogmatic theology which expressed the consubstantiality of the Father and the Son, or their co-eternity, or their attributive characteristics were accepted by them, although these terms were not included in the letter of the Scriptures.

He was aware of the different opinions for the Holy Spirit, which were supported by the Christians of his era, but he chose to characterize the Spirit as God. He stayed confident that if Christians asserted the divinity of the Spirit, they would eventually be led by the Spirit to proclaim Him as consubstantial with the Father. He fought for the recognition of the deity of Holy Spirit and he was named as theologian, because he had the dynamic purpose to spell out the clearest Neo-Nicene theology of the divine theology of the Spirit of God ${ }^{67}$. And he concludes that "If the Holy Spirit is not God, then the baptized do not participate by grace in the divine life of the Holy Trinity" ${ }^{\prime 6}$.

\section{(Summary)}

Gregory of Nazianzus had to confront with courage the heretical teaching about the divine nature of Holy Spirit. Through his works, he identifies The Holy Spirit as the third Person of the Triune God. One can see that the Bible clearly teaches that the Spirit is God. The Holy Spirit just as the Son, originates from the Father, is coeternal with the Father and illuminates the whole creation. The third Person of Trinity deserves to be worshipped as God and deifies people in their baptism. Gregory wonders: "For if $\mathrm{He}$ is not to be worshipped, how can He deify me by Baptism? But if He is to be worshipped, surely He is an Object of adoration, and if an Object of adoration He must be God; the one is linked to the other, a truly golden and saving chain. And indeed from the Spirit comes our New Birth, and from the New Birth our new creation, and from the new creation our deeper knowledge of the dignity of Him from Whom it is derived" (Oratio 31, 28). Gregory underlined the divinity of Holy Spirit and also explained the soteriological goal of this teaching, because: "If he has the same rank as I have, how can he make me God, or how can he join me with deity" (Oratio 31, 4).

\footnotetext{
${ }^{67}$ Cf. McGuckin, St. Gregory of Nazianzus, p. 92.

${ }^{68}$ Cf. Gregorius Nazianzenus, Oratio 31 (Theologica Quinta-De Spiritu Sancto) 4, PG 36, 137A.
} 


\section{BÓSTWO OSOBY DUCHA ŚWIĘTEGO \\ W NAUCZANIU GRZEGORZA Z NAZJANZU}

\section{(Streszczenie)}

Grzegorz z Nazjanzu musiał zmierzyć się z odwagą heretyckich twierdzeń dotyczących Boskiej natury Ducha Świętego. W swoich dziełach utożsamia on Ducha Świętego z trzecią osobą Trójcy Świętej. Zwraca uwagę, że Biblia wyraźnie naucza, iż Duch jest Bogiem. Duch Święty, tak jak Syn, pochodzi od Ojca, jest współwieczny z Ojcem i oświeca całe stworzenie. Trzecia Osoba Trójcy zasługuje na to, by być czczona jako Bóg i przebóstwia ludzi w momencie chrztu. Grzegorz rozważa: „Jeśli nie należy Mu oddawać czci, to jak może On przebóstwiać mnie przez chrzest? Ale jeśli należy oddawać mu cześć, to rzeczywiście staje się przedmiotem uwielbienia, a jeśli jest przedmiotem uwielbienia, to musi być Bogiem; jedno zależy od drugiego, prawdziwie złoty i zbawczy łańcuch. I rzeczywiście od Ducha pochodzą nasze nowe narodziny, a od nowego narodzenia nasze nowe stworzenie, a od nowego stworzenia nasze głębsze poznanie godności Tego, od którego to pochodzi" (Oratio 31, 28). Grzegorz podkreślał boskość Ducha Swiętego, a także wyjaśnił soteriologiczny cel tej nauki: ,Jeżeli jest w jednym szeregu ze mną, to jak może uczynić mnie Bogiem, albo jak złączyć z Bóstwem ,, (Oratio 31, 4).

Key words: Gregory Nazianzen, Holy Spirit, Triune God, Bible, Baptism, Second Ecumenical Council, Pneumatology.

Słowa kluczowe: Grzegorz z Nazjanzu, Duch Święty, Trójjedyny Bóg, Biblia, chrzest, II Sobór Ekumeniczny, pneumatologia.

\section{BIBLIOGRAPHY}

\section{Sources}

Athanasius Alexandrinus, Orationes adversus Arianos, PG 26, 12-523.

Athenagoras, Legatio pro Christianis, PG 6, 870-974, transl. B.P. Pratten, ANF 2, ed.

A. Roberts - J. Donaldson - A.C. Coxe, Buffalo - New York 1885, 129-148.

IRENAEus, Adversus haereses, PG 7, 9-1225, transl. A. Roberts - W. Rambaut, ANF 1, ed.

A. Roberts - J. Donaldson - A.C. Coxe, Buffalo - New York 1885, 315-567.

Gregorius Nazianzenus, Epistulae 58, PG 37, 21-388, transl. C.G. Browne - J.E. Swallow, NPNF Series II, vol. 7, ed. P. Schaff - H. Wace, Buffalo - New York 1894, 437-482.

Gregorius Nazianzenus, Orationes, PG 36, 12-664, transl. C.G. Browne - J.E. Swallow, NPNF Series II, vol. 7, ed. P. Schaff - H. Wace, Buffalo - New York 1894, 203-434.

Gregorius Nyssenus, Epistula 189, PG 32, 684-694, transl. H.A. Wilson, NPNF Series II, vol. 5, ed. P. Schaff - H. Wace, Buffalo - New York 1893, 326-330.

Origenes, De Principiis, ed. P. Koetschau, transl. G.W. Butterworth: Origen, On First Principles, New York 1973.

Socrates, Historia ecclesiastica, PG 67, 30A - 841B, transl. A.C. Zenos, NPNF Series II, vol. 2, ed. P. Schaff - H. Wace, Buffalo - New York 1890, 1-178. 


\section{Literature}

Artemi E., Gregory Nazianzen's trinitarian teaching based on his Twentieth Theological Oration, "De Medio Aevo" 4 (2013) fasc. 2, 127-146.

BeEley Ch., Gregory of Nazianzus on the Trinity and the Knowledge of God, Oxford 2008. Brown H.O.J., Heresies: Heresy and Orthodoxy in the History of the Church, Peabody 1988.

Cash B., Origen's Trinitarian Theology, New York 2010.

Christou P., Patrologia, vol. 1, Thessaloniki 2005.

FeIDAs V., Ecclesiastic History, vol. 1, Athens 1992.

Lampe G.H., Christian Theology in Patristic Period, in: A History of Christian Doctrine, ed. H. Cunliffe-Jones - B. Drewery, Edinburgh 1978, 21-180.

Lo C.F. Gregory Nazianzen's Pneumatology completes the $4^{\text {th }}$ century trinitarian theology, The Johns Hopkins University, Charlotte, North Carolina 2011.

McGuckin J.A., St. Gregory of Nazianzus: An Intellectual Biography, Crestwood - New York 2001.

Nofziger Ch.J., Reign of heretics: Arianism and political power in the Vandal and Ostrogothic kingdoms, Western Washington University, Masters Thesis Collection, Washington 2012.

Papadopoulos S., Patrologia, vol. 1-2, Athens 1990-1992.

Papadopoulos S., Gregory the theologian and the presuppositions of his pneumatology, vol. 2, Athens $1989^{3}$.

Reynolds S., Introduction, in: Gregory of Nazianzus, Five Theological Orations, Translated with an introduction and notes by S. Reynolds, Toronto 2011, V-VI [= https:// tspace.library.utoronto.ca/bitstream/1807/36303/1/Gregory\%20of $\% 20$ Nazianzus $\% 20$ Theological\%20Orations.pdf (access 15.03.2017)].

Romanides J., Dogmatic and Symbolic Theology of the Orthodox Catholic Church, vol. 1, Athens 1960.

Schaff P., History of the Christian Church: Nicene and post-Nicene Christianity from Constantine the Great to Gregory the Great, A.D. 311-600, vol. 3, New York 1997.

Stefanides B., Church History, Athens 1959.

Swete H.B., The Holy Spirit in the Ancient Church, London 1912.

Trevett C., Montanism: Gender, Authority and the New Prophecy, Cambridge 1996.

ZuRAB J., Theologia and oikonomia: the soteriological ground of Gregory of Nazianzus trinitarian theology, Durham 2010. 